Volume-VI, Number-01, January-June, 2011

\title{
Risk Management Practices: A Critical Diagnosis of Some Selected Commercial Banks in Bangladesh
}

\author{
MD. ZAHANGIR ALAM* \\ MD. MASUKUJJAMAN ${ }^{* *}$
}

\begin{abstract}
The paper is about risk management practices of commercial banks in Bangladesh based on five commercial banks operating in Bangladesh. The number of respondents was 25, five from each bank. While collecting the requisite data, five points Likert Scale has been used. The objective of the study was to critically examine risk management practices of Bangladeshi banks i.e., types of risk facing a bank, procedure and techniques used to minimize the risk etc. The study also examines how far the banks follow the guidelines of Bangladesh Bank regarding risk management. The study reveals that credit risk, market risk and operational risk are the major risks to the bankers which are managed through three layers of management system. The Board of Directors performs the responsibility of the main risk oversight, the Executive Committee monitors risk and the Audit Committee oversees all the activities of banking operations. In the context of opinions regarding use of risk management techniques, it is found that internal rating system and risk adjusted rate of return on capital are relatively more important techniques used by banks.
\end{abstract}

Key Words: Risk, Risk Management, Risk Management Techniques, Banking.

\section{INTRODUCTION}

In the past two decades, the banking industry has evolved from a financial intermediation between depositors and borrowers, to a "one-stop" centre for a range of financial services like insurance, investments and mutual funds. The advancement of information and communicative technology (ICT) is given credit for the evolution of banking services, in particular, online banking. The development in ICT has not only provided vast banking opportunities previously beyond reach, but also heightens the competition and risks faced by banks in the financial system. (Voon-Choong, et al., 2010).

\footnotetext{
*Assistant Professor of Finance, Department of Business Administration, International Islamic University Chittagong, Dhaka Campus.

${ }^{* *}$ Lecturer in Finance, Department of Business Administration, Northern University Bangladesh, Dhaka.
} 
Risk is the deviation of the expected outcome. In one way, risk can be classified as business risk and financial risk. Business risk arises from the nature of a firm's business which relates to factors affecting the product market. Financial risk arises from possible losses in financial markets due to movements in financial variables (Jorion and Sarkis, 1996). It is usually associated with leverage with the risk that obligations and liabilities cannot be met with current assets (Gleason, 2000).

Another way of decomposing risk is systematic risk and unsystematic risk. Systematic risk is associated with the overall market or the economy and it can be mitigated in a large diversified portfolio, whereas unsystematic risk is linked to a specific asset or firm and cannot be diversified though its parts can be reduced through mitigation and transferring techniques (Santomero, 1997). However, some risks cannot be eliminated or transferred and must be absorbed by the banks. The first is due to the complexity of the risk and difficulty in separating it from asset. The second risk is accepted by the financial institutions as these are central to their business. These risks are accepted because the banks are specialized in dealing with them and get rewarded accordingly. The objective of financial institutions is to maximize profit and shareholder value-added by providing different financial services mainly by managing risks. (Khan and Ahmad, 2001)

Bangladesh Bank, the prime supervisory authority of the financial sector implemented the new capital standard - Basel II from January 2009 in parallel with Basel I. From January 01, 2010 Basel II has been solely implemented in the banking sector. Basel II requires addressing and managing the market risk and operational risk in addition to the existing (as per Basel I) credit risk. Basel II capital standard is acting as a major catalyst for enrichment of risk management practices within the bank embedding the risk culture in the bank's operation. In response to the new capital accord (Basel II), risk management process within the bank has been introduced supporting the principles of more risk sensitive approach to capital adequacy.

Banks and similar financial institutions need to meet forthcoming regulatory requirements for risk measurement and capital. However, it is a serious error to think that meeting regulatory requirements is the sole or even the most important reason for establishing a sound, scientific risk management system. Managers need reliable risk measures to direct capital to activities with the best risk/reward ratios. They need estimates of the size of potential losses to stay within limits imposed by readily available liquidity, by creditors, customers, and regulators. They need mechanisms to monitor positions and create incentives for prudent risk-taking by divisions and individuals (Pyle, 1997).Risk measurement deals 
with quantification of risk exposures, whereas risk management refers to the overall process by which managers satisfy these needs and follows to define a business strategy, to identify the risks to which it is exposed, to quantify those risks, and to understand and control the nature of risks it faces. (Cumming and Beverly, 2001)

Most of the parties involved in bank-dealings suffer from the following limitations: i) lack of proper identification of the determinants related to bankdealings; ii) failure to properly identifying risks involved in banking transaction; and iii) lack of knowledge to manage the risks faced by banks. All these necessity call for an in-depth investigation on risk management practices and here lies the justification of this study.

\section{OBJECTIVES THE STUDY}

The main objective of the study is to diagnose the risk management practices of some selected commercial banks operating in Bangladesh. To attain the key objective, the following are listed as the specific objectives:

i. To identify the risks faced by the selected banks.

ii. To trace out the process and system of risk management.

iii. To examine the techniques of risk management by the sample Banks.

iv. To evaluate whether the banks under study follow the guidelines of Bangladesh Bank regarding risk management.

\section{METHODOLOGY OF THE STUDY}

It is a descriptive research based on survey. The study is the based on the primary data. The primary data, on types of risk, techniques to measure risk etc. have been collected through a structured questionnaire. In the questionnaire, only closed ended options have been considered. Five profitable commercial banks, namely Mercantile Bank Ltd., Dhaka Bank Ltd., Bank Asia Ltd., Prime Bank Ltd. and Jamuna Bank Ltd. have been selected for the study. A total number of twenty five bankers, five from each bank have been interviewed. The status of each respondent (banker) is senior officer or above who carries out risk management activities of the banks under study. The collected data have been processed with the help of the computer by using statistical software. Five point Likert -Scale has been used to analyze the data. 


\section{THEORETICAL FRAMEWORK}

\section{Risks faced by banks}

The commercial Banks usually face the following risks:

\section{Credit Risk}

It is the potential loss arising from the failure of a borrower to meet its obligations in accordance with agreed terms. Credit risk is one of the oldest and most vital forms of risk faced by banks as financial intermediaries (Broll, et al., 2002). Commercial banks are most likely to make a loss due to credit risk (Bo, et al., 2005). Generally, the greater the credit risk, the higher the credit premiums to be charged by banks, leading to an improvement in the net interest margin (Hanweck and Ryu, 2004).

\section{Market Risk}

The risk of loss from adverse movement in financial market rates (interest and exchange rate) and bond, equity or commodity prices. A bank's market risk exposure is determined by both the volatility of underlying risk factors and the sensitivity of the bank's portfolio to movements in those risk factors (Hendricks and Hirtle, 1997).

The risk of changes in income of the bank as a result of movements in market interest rates. Interest rates risk is a major concern for banks due to the nominal nature of their assets and the asset-liability maturity mismatch (Hasan and Sarkar, 2002). Some researchers emphasized that higher interest rates had positive impact on banks (Hanweck and Ryu, 2004; Hyde, 2007).

It arises from potential change in earnings resulted from exchange rate fluctuations, adverse exchange positioning or change in the market prices managed by the Treasury Division.

\section{Equity Risk}

It is the risk of loss due to adverse change in market price of equities held by the bank.

Operational Risk: The potential financial loss as a result of a breakdown in day-to-day operational processes. Operational risk does not mean only failures in the bank's operations, but also the causes of the failures, such as terrorist attacks, management failures, competitive actions and natural disasters (King, 1998). These caused are largely uncontrollable and unpredictable. Moreover, human or technological errors, lack of control to prevent unauthorized or inappropriate 
transactions being made, fraud and faulty reporting may lead to further losses caused by internal process, people and operating system (Medova, 2001).

\section{Money Laundering Risk}

It arises from the practice of disguising the origins of illegally-obtained money (drug dealing, corruption, accounting fraud and other types of fraud, and tax evasion, etc.) through banking channel and the proceeds of crime are made to appear legitimate (Wikipedia).

\section{Information Technology Risk}

It is related to IT, such as network failure, lack of skills, hacking, virus attack and poor integration of system.

\section{Liquidity Risk}

It generates from the failure or inability to meet current and future financial obligations by bank due to shortfall of cash or cash equivalent assets. Banks are exposed to liquidity risk where the more liquidity is generated, the greater are the possibility and severity of losses associated with having to dispose of illiquid assets to meet the liquidity demands of depositor (Diamond 1999; Allen and Jagtiani, 1996). However, besides depositors, (Gatev, 2006) revealed that banks that make commitments to lend are exposed to the risk of unexpected liquidity demands from their borrowers.

\section{Marketing Risk}

This risk is related to the different aspects of the promotion and branding of the bank, including image management, product promotion and advertising.

\section{Human Resource Risk}

This type of risk is generated within the bank from failure to recruit the right people in the right place, inappropriate means of recruitment, failure to provide feedback to the employees on performance, over-reliance on key personnel, inappropriate training and development etc. 


\section{Risk Management Process}

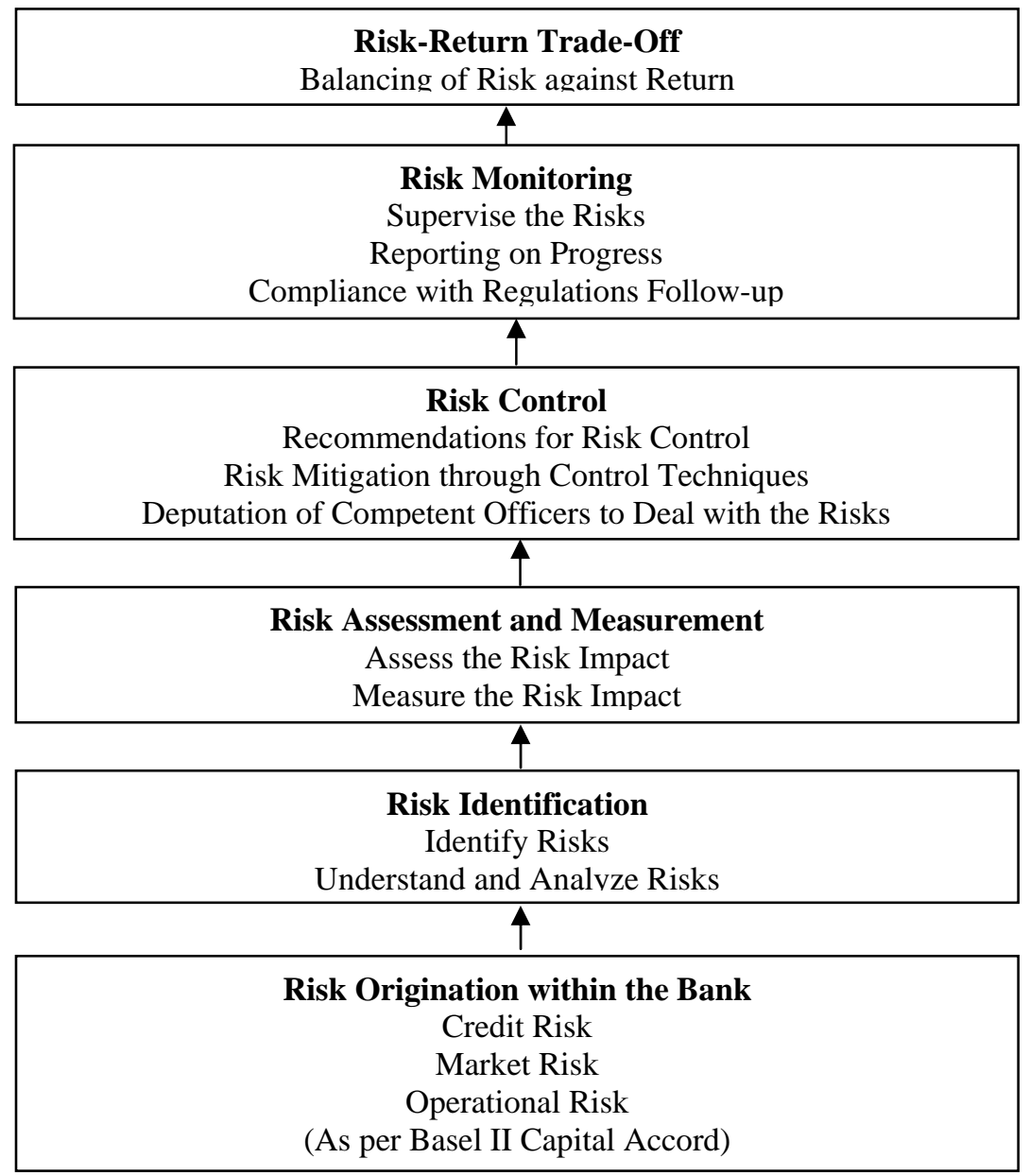

Source: Annual Report of Mercantile Bank Ltd. -2009

\section{Risk Management Approach}

It is important not only for fulfilling regulatory requirements but also to improve financial and operational performance of the banks. Strong and integrated risk management is essential for the long-term sustainability of the bank's business. The comprehensive risk management policies and sophisticated risk management processes are required for systematic identification, measurement, monitoring and controlling of all business risks. 
Bank's overall financial soundness can be measured only by adopting a strong risk management process communicating concise risk management standards to all concerned officials through adequate policies, directives, operating procedures and training programs.

\section{Risk Management Oversight}

TABLE -01

THREE LINE OF DEFENSE CONCEPT FOR RISK MANAGEMENT

\begin{tabular}{|c|c|c|}
\hline First Line of Defense & Second Line of Defense & Third Line of Defense \\
\hline$>$ Branch & Risk Management & \multirow{3}{*}{$\begin{array}{ll}> & \text { Board of Directors } \\
> & \text { Executive Committee } \\
> & \text { Audit Committee }\end{array}$} \\
\hline Level & Divisions & \\
\hline & $\begin{array}{l}\text { Risk Management } \\
\text { Committees }\end{array}$ & \\
\hline
\end{tabular}

Source: Annual Report of Mercantile Bank Ltd. -2009

\section{Techniques of Risk Management}

\section{GAP Analysis}

It is an interest rate risk management tool based on the balance sheet which focuses on the potential variability of net-interest income over specific time intervals. In this method a maturity/ re-pricing schedule that distributes interestsensitive assets, liabilities, and off-balance sheet positions into time bands according to their maturity (if fixed rate) or time remaining to their next repricing (if floating rate), is prepared. These schedules are then used to generate indicators of interest-rate sensitivity of both earnings and economic value to changing interest rates. After choosing the time intervals, assets and liabilities are grouped into these time buckets according to maturity (for fixed rates) or first possible re-pricing time (for flexible rates). The assets and liabilities that can be re-priced are called rate sensitive assets (RSAs) and rate sensitive liabilities (RSLs) respectively. Interest sensitive gap (DGAP) reflects the differences between the volume of rate sensitive asset and the volume of rate sensitive liability and given by,

$$
\text { GAP }=\text { RSAs }- \text { RSLs }
$$

The information on GAP gives the management an idea about the effects on net-income due to changes in the interest rate. Positive GAP indicates that an increase in future interest rate would increase the net interest income as the change in interest income is greater than the change in interest expenses and vice versa. (Cumming and Beverly, 2001). 


\section{Duration-GAP Analysis}

It is another measure of interest rate risk and managing net interest income derived by taking into consideration all individual cash inflows and outflows. Duration is value and time weighted measure of maturity of all cash flows and represents the average time needed to recover the invested funds. Duration analysis can be viewed as the elasticity of the market value of an instrument with respect to interest rate. Duration gap (DGAP) reflects the differences in the timing of asset and liability cash flows and given by,

$D G A P=D A-u D L$

Where $\boldsymbol{D A}$ is the average duration of the assets, $\boldsymbol{D} \boldsymbol{L}$ is the average duration of liabilities, and $\boldsymbol{u}$ is the liabilities/assets ratio. When interest rate increases by comparable amounts, the market value of assets decrease more than that of liabilities resulting in the decrease in the market value of equities and expected net-interest income and vice versa. (Cumming and Beverly, 2001)

\section{Value at Risk (VaR)}

It is one of the newer risk management tools. The Value at Risk (VaR) indicates how much a firm can lose or make with a certain probability in a given time horizon. VaR summarizes financial risk inherent in portfolios into a simple number. Though VaR is used to measure market risk in general, it incorporates many other risks like foreign currency, commodities, and equities. ( Jorion, 2001)

\section{Risk Adjusted Rate of Return on Capital (RAROC)}

It gives an economic basis to measure all the relevant risks consistently and gives managers tools to make the efficient decisions regarding risk/return tradeoff in different assets. As economic capital protects financial institutions against unexpected losses, it is vital to allocate capital for various risks that these institutions face. Risk Adjusted Rate of Return on Capital (RAROC) analysis shows how much economic capital different products and businesses need and determines the total return on capital of a firm. Though Risk Adjusted Rate of Return can be used to estimate the capital requirements for market, credit and operational risks, it is used as an integrated risk management tool (Crouhy and Robert, 2001).

\section{Securitization}

It is a procedure studied under the systems of structured finance or credit linked notes. Securitization of a bank's assets and loans is a device for raising new funds and reducing bank's risk exposures. The bank pools a group of income-earning assets (like mortgages) and sells securities against these in the 
open market, thereby transforming illiquid assets into tradable asset backed securities. As the returns from these securities depend on the cash flows of the underlying assets, the burden of repayment is transferred from the originator to these pooled assets.

\section{Sensitivity Analysis}

It is very useful when attempting to determine the impact, the actual outcome of a particular variable will have if it differs from what was previously assumed. By creating a given set of scenarios, the analyst can determine how changes in one variable(s) will impact the target variable.

\section{Internal Rating System}

An internal rating system helps financial institutions manage and control credit risks they face through lending and other operations by grouping and managing the credit-worthiness of borrowers and the quality of credit transactions.

\section{FINDINGS AND ANALYSIS}

\section{Categories of bank risks}

In order to get the perception of bankers regarding various types of bank's risks, 25 bankers have been interviewed. Their responses have been tabulated in Table: 02 which reveals that credit risk occupies first rank and weighted average score being 4.08; followed by market risk; operational risk; interest rate risk; foreign exchange risk; equity risk; liquidity risk; money laundering risk; marketing risk \& human resource risk, weighted average scores being 4.04; 3.96; 3.72; 3.60; 3.56; 3.40; 3.32; 3.20; $3.16 \& 3.08$ respectively. 
TABLE- 02

PERCEPTION OF BANKERS REGARDING BANKS RISK

\begin{tabular}{|c|c|c|c|c|c|c|c|}
\hline Risk & $\begin{array}{l}\text { Very } \\
\text { Low } \\
(\%)\end{array}$ & $\begin{array}{l}\text { Low } \\
(\%)\end{array}$ & $\begin{array}{c}\text { Neutral } \\
(\%)\end{array}$ & $\begin{array}{l}\text { High } \\
(\%)\end{array}$ & $\begin{array}{c}\text { Very } \\
\text { High } \\
(\%)\end{array}$ & WAS & Ranks \\
\hline Operational Risk & 0 & 4 & 16 & 60 & 20 & 3.96 & 3rd \\
\hline Credit Risk & 0 & 8 & 24 & 36 & 32 & 4.08 & $1^{\mathrm{st}}$ \\
\hline $\begin{array}{l}\text { Human Resource } \\
\text { Risk }\end{array}$ & 0 & 32 & 36 & 24 & 8 & 3.08 & $11^{\text {th }}$ \\
\hline Market Risk & 0 & 8 & 28 & 32 & 32 & 4.04 & $2^{\text {nd }}$ \\
\hline $\begin{array}{l}\text { Information } \\
\text { Technology Risk }\end{array}$ & 8 & 12 & 28 & 44 & 8 & 3.20 & $9^{\text {th }}$ \\
\hline Equity Risk & 4 & 16 & 36 & 12 & 32 & 3.56 & $6^{\text {th }}$ \\
\hline $\begin{array}{l}\text { Foreign Exchange } \\
\text { Risk }\end{array}$ & 4 & 12 & 24 & 40 & 20 & 3.60 & $5^{\text {th }}$ \\
\hline Interest Rate Risk & 0 & 12 & 28 & 36 & 24 & 3.72 & $4^{\text {th }}$ \\
\hline Liquidity Risk & 0 & 12 & 36 & 32 & 20 & 3.40 & $7^{\text {th }}$ \\
\hline $\begin{array}{l}\text { Money } \\
\text { Laundering Risk }\end{array}$ & 0 & 24 & 32 & 32 & 12 & 3.32 & $8^{\text {th }}$ \\
\hline Marketing Risk & 0 & 8 & 24 & 44 & 24 & 3.16 & $10^{\text {th }}$ \\
\hline
\end{tabular}

Source: Field Survey, 2010

Note: WAS stands for Weighted Average Score. Weighted average score is calculated using weights as follows: very low $=1$, low $=2$, neutral $=3$, high $=4$ and very high $=5$

\section{Layers of Risk Management/Risk Management Oversight}

Table-03 depicts that out of six aspects regarding risk management oversight, the Board of Directors performs the responsibility of the main risk oversight \& the Executive Committee monitors risk occupy the first position in bracket weighted average score being 3.78 each; followed by the Audit Committee oversees all the activities of banking operations; the management at divisional level monitors risk; branch level officials supervise risk, weighted average scores being 3.72; $3.24 \& 3.08$ respectively. 
TABLE-03

OPINIONS OF BANKERS REGARDING RISK MANAGEMENT OVERSIGHT

\begin{tabular}{|c|c|c|c|c|c|c|c|}
\hline Steps & $\begin{array}{l}\text { Never } \\
(\%)\end{array}$ & $\begin{array}{c}\text { Seldom } \\
(\%)\end{array}$ & $\begin{array}{c}\text { Sometimes } \\
\text { (\%) }\end{array}$ & $\begin{array}{c}\text { Often } \\
(\%)\end{array}$ & $\begin{array}{c}\text { Always } \\
(\%)\end{array}$ & WAS & Ranks \\
\hline $\begin{array}{l}\text { The management at } \\
\text { divisional level } \\
\text { monitors risk. }\end{array}$ & 0 & 36 & 20 & 28 & 16 & 3.24 & $4^{\text {th }}$ \\
\hline $\begin{array}{l}\text { The Board of Director } \\
\text { performs the } \\
\text { responsibility of the } \\
\text { main risk oversight. }\end{array}$ & 0 & 12 & 32 & 24 & 32 & 3.76 & $1.5^{\text {th }}$ \\
\hline $\begin{array}{l}\text { Branch level officials } \\
\text { supervise risk. }\end{array}$ & 0 & 32 & 40 & 24 & 4 & 3.08 & $5^{\text {th }}$ \\
\hline $\begin{array}{l}\text { The Executive } \\
\text { Committee monitors } \\
\text { risk. }\end{array}$ & 0 & 12 & 20 & 48 & 20 & 3.76 & $1.5^{\text {th }}$ \\
\hline $\begin{array}{l}\text { The Audit Committee } \\
\text { oversees all the } \\
\text { activities of banking } \\
\text { operations. }\end{array}$ & 0 & 8 & 32 & 40 & 20 & 3.72 & $3^{\text {rd }}$ \\
\hline
\end{tabular}

Source: Field Survey, 2010

\section{Individual Risk Management of Banks}

\section{Credit Risk Management}

Table -04 reveals that among 11 measures regarding managing credit risk, bank uses the updated credit policy approved by the Board of Directors occupies first rank, weighted average score being 4.04; followed by credit risk management division and credit administration division perform their activities separately weighted average score being 3.9; Law \& recovery team monitor the performance of the loans \& Internal Control \& Compliance Division directly report to the Board/ Audit Committee about the overall credit risk, in bracket weighted average score 3.68 each; bank follows the central bank's instructions in determining the single borrower/ large loan limit; bank professionally follows five Cs principles in the credit evaluation stage; performance of loans is regularly monitored to set up early warning system; bank maintains provision \& suspension of interest; bank diversifies its loan exposure to different sectors; bank takes initiatives to encourage the borrowers of the bank for rating by

External Credit Assessment Institutions; bank measures its loan portfolio in terms of payment arrears ,weighted average scores being 3.44; 3.32; 3.24; 3.12; 3.08; $2.88 \& 2.80$ respectively. 
TABLE 04

OPINIONS REGARDING CREDIT RISK MANAGEMENT

\begin{tabular}{|c|c|c|c|c|c|c|c|}
\hline Steps & $\begin{array}{c}\text { Never } \\
(\%)\end{array}$ & $\begin{array}{c}\text { Seldom } \\
\text { (\%) }\end{array}$ & $\begin{array}{c}\text { Sometimes } \\
(\%)\end{array}$ & $\begin{array}{c}\text { Often } \\
(\%)\end{array}$ & $\begin{array}{c}\text { Always } \\
\text { (\%) }\end{array}$ & WAS & Ranks \\
\hline $\begin{array}{l}\text { Internal Control \& Compliance } \\
\text { division directly report to the } \\
\text { Board/ Audit Committee about } \\
\text { the overall credit risks. }\end{array}$ & 0 & 16 & 24 & 36 & 24 & 3.68 & $3.5^{\text {th }}$ \\
\hline $\begin{array}{l}\text { Bank uses the updated credit } \\
\text { policy approved by the board } \\
\text { of directors. }\end{array}$ & 0 & 4 & 24 & 36 & 36 & 4.04 & $1^{\mathrm{st}}$ \\
\hline $\begin{array}{l}\text { Bank follows the central banks } \\
\text { instructions in determining the } \\
\text { single borrower/ large loan } \\
\text { limit. }\end{array}$ & 0 & 20 & 36 & 24 & 20 & 3.44 & $5^{\text {th }}$ \\
\hline $\begin{array}{l}\text { Credit Risk Management } \\
\text { Division and Credit } \\
\text { Administration division } \\
\text { perform their activities } \\
\text { separately. }\end{array}$ & 0 & 8 & 26 & 36 & 32 & 3.92 & $2^{\text {nd }}$ \\
\hline $\begin{array}{l}\text { Bank professionally follows } 5 \\
\text { Cs principles in the credit } \\
\text { evaluation stage. }\end{array}$ & 0 & 28 & 32 & 20 & 20 & 3.32 & $6^{\text {th }}$ \\
\hline $\begin{array}{l}\text { Law \& Recovery team monitor } \\
\text { the performance of the loans. }\end{array}$ & 0 & 12 & 32 & 24 & 32 & 3.68 & $3.5^{\text {th }}$ \\
\hline $\begin{array}{l}\text { Bank takes initiatives to } \\
\text { encourage the borrowers for } \\
\text { rating by External Credit } \\
\text { Assessment Institutions. }\end{array}$ & 4 & 28 & 48 & 20 & 0 & 2.88 & $10^{\text {th }}$ \\
\hline $\begin{array}{l}\text { Bank maintains provision \& } \\
\text { suspension of interest. }\end{array}$ & 0 & 28 & 36 & 32 & 4 & 3.12 & $8^{\text {th }}$ \\
\hline $\begin{array}{l}\text { Performance of loans is } \\
\text { regularly monitored to set up } \\
\text { early warning system. }\end{array}$ & 8 & 12 & 28 & 32 & 20 & 3.24 & $7^{\text {th }}$ \\
\hline $\begin{array}{l}\text { Bank diversifies its loan } \\
\text { exposure to different sectors. }\end{array}$ & 8 & 16 & 48 & 24 & 4 & 3.08 & $9^{\text {th }}$ \\
\hline $\begin{array}{l}\text { Bank measures its loan } \\
\text { portfolio in terms of payment } \\
\text { arrears. }\end{array}$ & 12 & 28 & 40 & 20 & 0 & 2.80 & $11^{\text {th }}$ \\
\hline
\end{tabular}

Source: Field Survey, 2010

\section{Operational Risk Management}

Table- 05 depicts that among three steps regarding managing operational risk, operational risk is monitored \& controlled within the bank through an operational risk management framework occupies first rank, weighted average 
score being 4.24; followed by bank comply with the regulatory requirements and appropriate training is arranged for the employees for becoming aware of the regulations, weighted average score being $2.76 \& 1.32$ respectively.

TABLE-5

OPINIONS REGARDING OPERATIONAL RISK MANAGEMENT

\begin{tabular}{|c|c|c|c|c|c|c|c|}
\hline Steps & $\begin{array}{c}\text { Never } \\
(\%)\end{array}$ & $\begin{array}{c}\text { Seldom } \\
(\%)\end{array}$ & $\begin{array}{c}\text { Sometimes } \\
\text { (\%) }\end{array}$ & $\begin{array}{l}\text { Often } \\
(\%)\end{array}$ & $\begin{array}{c}\text { Always } \\
(\%)\end{array}$ & WAS & Ranks \\
\hline $\begin{array}{l}\text { Bank complies } \\
\text { with the } \\
\text { regulatory } \\
\text { requirements. }\end{array}$ & 0 & 48 & 28 & 24 & 0 & 2.76 & $2^{\text {nd }}$ \\
\hline $\begin{array}{l}\text { Operational } \\
\text { risk is } \\
\text { monitored \& } \\
\text { controlled } \\
\text { within the Bank } \\
\text { through an } \\
\text { operational risk } \\
\text { management } \\
\text { framework. }\end{array}$ & 0 & 0 & 20 & 36 & 44 & 4.24 & $1^{\mathrm{st}}$ \\
\hline $\begin{array}{l}\text { Appropriate } \\
\text { training is } \\
\text { arranged for the } \\
\text { employees for } \\
\text { becoming } \\
\text { aware of the } \\
\text { regulations. }\end{array}$ & 68 & 32 & 0 & 0 & 0 & 1.32 & $3^{\text {rd }}$ \\
\hline
\end{tabular}

Source: Field Survey, 2010

\section{Money Laundering Risk Management}

Table -06 depicts that out of four measures regarding managing money laundering risk, The Central Compliance Unit looks after the overall compliance with money laundering regulations occupies first rank, weighted average score being 3.08 followed by Chief Anti-money Laundering Compliance officer takes initiatives to implement and enforce anti-money laundering policies and procedures; Trainings \& workshops on anti-money laundering are arranged for the employees and suspicious transactions reported to the appropriate authorities for their immediate actions, weighted average scores being 3.76; 3.68 and 1.20 respectively. 
TABLE 6

OPINIONS REGARDING MONEY LAUNDERING

RISK MANAGEMENT

\begin{tabular}{|c|c|c|c|c|c|c|c|}
\hline Measures & $\begin{array}{c}\text { Never } \\
(\%)\end{array}$ & $\begin{array}{c}\text { Seldom } \\
(\%)\end{array}$ & $\begin{array}{c}\text { Sometimes } \\
(\%)\end{array}$ & $\begin{array}{c}\text { Often } \\
(\%)\end{array}$ & $\begin{array}{c}\text { Always } \\
(\%)\end{array}$ & WAS & Ranks \\
\hline $\begin{array}{l}\text { Trainings \& } \\
\text { workshops on } \\
\text { anti-money } \\
\text { laundering are } \\
\text { arranged for the } \\
\text { employees. }\end{array}$ & 4 & 8 & 32 & 28 & 28 & 3.68 & $3^{\text {rd }}$ \\
\hline $\begin{array}{l}\text { The Central } \\
\text { Compliance Unit } \\
\text { looks after the } \\
\text { overall } \\
\text { compliance with } \\
\text { money } \\
\text { laundering } \\
\text { regulations. }\end{array}$ & 0 & 0 & 20 & 32 & 48 & 3.80 & $1^{\text {st }}$ \\
\hline $\begin{array}{l}\text { Chief Anti- } \\
\text { money } \\
\text { Laundering } \\
\text { Compliance } \\
\text { Officer takes } \\
\text { initiatives to } \\
\text { implement \& } \\
\text { enforce anti- } \\
\text { money } \\
\text { laundering } \\
\text { policies \& } \\
\text { procedures. }\end{array}$ & 4 & 12 & 20 & 32 & 32 & 3.76 & $2^{\text {nd }}$ \\
\hline $\begin{array}{l}\text { Suspicious } \\
\text { transactions } \\
\text { reported to the } \\
\text { appropriate } \\
\text { authorities for } \\
\text { their immediate } \\
\text { actions. }\end{array}$ & 80 & 20 & 0 & 0 & 0 & 1.20 & $4^{\text {th }}$ \\
\hline
\end{tabular}

Source: Field Survey, 2010

\section{Equity Risk Management}

Table -07 reveals that three steps regarding equity risk management, bank follows Market-to-Market valuations of the share investment portfolio in measuring and identifying risk occupies first rank, weighted average score being 3.96: followed by bank diversifies investment to minimize equity risk and margin accounts are monitored very closely, weighted average scores being 3.84 and 3.76 respectively. 
TABLE 7

OPINIONS REGARDING EQUITY RISK MANAGEMENT

\begin{tabular}{|c|c|c|c|c|c|c|c|}
\hline Measures & $\begin{array}{c}\text { Never } \\
(\%)\end{array}$ & $\begin{array}{c}\text { Seldom } \\
(\%)\end{array}$ & $\begin{array}{c}\text { Sometimes } \\
\text { (\%) }\end{array}$ & $\begin{array}{l}\text { Often } \\
(\%)\end{array}$ & $\begin{array}{c}\text { Always } \\
\text { (\%) }\end{array}$ & WAS & Ranks \\
\hline $\begin{array}{l}\text { Bank } \\
\text { diversifies } \\
\text { investment to } \\
\text { minimize } \\
\text { equity risk. }\end{array}$ & 0 & 8 & 28 & 36 & 28 & 3.84 & $2^{\text {nd }}$ \\
\hline $\begin{array}{l}\text { Bank follows } \\
\text { Market -to- } \\
\text { Market } \\
\text { valuations of } \\
\text { the share } \\
\text { investment } \\
\text { portfolio in } \\
\text { measuring and } \\
\text { identifying } \\
\text { risk. }\end{array}$ & 0 & 4 & 24 & 44 & 28 & 3.96 & $1^{\mathrm{st}}$ \\
\hline $\begin{array}{l}\text { Margin } \\
\text { accounts are } \\
\text { monitored } \\
\text { very closely. }\end{array}$ & 0 & 8 & 32 & 36 & 24 & 3.76 & $3^{\text {rd }}$ \\
\hline
\end{tabular}

\section{Information Technology Risk Management}

Table -08 shows that out of two measures regarding equity risk management, IT Audit Team audits the divisions \& branches occupies first rank, weighted average score being 4.20; followed by readymade software and in-house software used ,weighted average scores being 2.76.

TABLE 8

OPINIONS REGARDING INFORMATION TECHNOLOGY RISK

\begin{tabular}{l|c|c|c|c|c|c|c}
\hline Measures & $\begin{array}{c}\text { Never } \\
(\%)\end{array}$ & $\begin{array}{c}\text { Seldom } \\
(\%)\end{array}$ & $\begin{array}{c}\text { Sometimes } \\
(\%)\end{array}$ & $\begin{array}{c}\text { Often } \\
(\%)\end{array}$ & $\begin{array}{c}\text { Always } \\
(\%)\end{array}$ & WAS & Ranks \\
\hline $\begin{array}{l}\text { Readymade } \\
\text { software \& in- } \\
\text { house software } \\
\text { used. }\end{array}$ & 4 & 4 & 4 & 28 & 28 & 2.76 & $2^{\text {nd }}$ \\
$\begin{array}{l}\text { IT Audit Team } \\
\text { audits the } \\
\text { divisions \& } \\
\text { branches. }\end{array}$ & 8 & 4 & 24 & 28 & 36 & 4.2 & $1^{\text {st }}$ \\
\hline
\end{tabular}

Source: Field Survey, 2010 


\section{Liquidity Risk Management}

Table -09 depicts that among four measures regarding liquidity risk management , bank maintains customers' confidence is maintained in ensuring liquidity occupies first rank, weighted average score being 4.04; followed by the Treasury Division maintains the current liquidity position, funding requirements \& sources of fund; assets and liabilities maturity are analyzed; the management maintains the liquidity contingency plan and bank follows the guidelines for the liability diversification and credit commitments, weighted average scores being 3.48 ; $3.44 ; 3.40$ and 3.36 respectively.

TABLE 9

OPINIONS REGARDING LIQUIDITY RISK MANAGEMENT

\begin{tabular}{|c|c|c|c|c|c|c|c|}
\hline Measures & $\begin{array}{c}\text { Never } \\
(\%)\end{array}$ & $\begin{array}{c}\text { Seldom } \\
(\%)\end{array}$ & $\begin{array}{c}\text { Sometimes } \\
(\%)\end{array}$ & $\begin{array}{c}\text { Often } \\
(\%)\end{array}$ & $\begin{array}{c}\text { Always } \\
(\%)\end{array}$ & WAS & Ranks \\
\hline $\begin{array}{l}\text { The management } \\
\text { maintains the } \\
\text { liquidity } \\
\text { contingency plan. }\end{array}$ & 8 & 16 & 28 & 24 & 24 & 3.40 & $4^{\text {th }}$ \\
\hline $\begin{array}{l}\text { Bank maintains } \\
\text { customers' } \\
\text { confidence is } \\
\text { maintained in } \\
\text { ensuring liquidity. }\end{array}$ & 0 & 0 & 32 & 32 & 36 & 4.04 & $1^{\mathrm{st}}$ \\
\hline $\begin{array}{l}\text { The treasury } \\
\text { division maintains } \\
\text { the current } \\
\text { liquidity position, } \\
\text { funding } \\
\text { requirements \& } \\
\text { sources of fund. }\end{array}$ & 8 & 16 & 24 & 20 & 28 & 3.48 & $2^{\text {nd }}$ \\
\hline $\begin{array}{l}\text { Bank follows the } \\
\text { guidelines for the } \\
\text { liability } \\
\text { diversification and } \\
\text { credit } \\
\text { commitments. }\end{array}$ & 12 & 8 & 28 & 32 & 20 & 3.36 & $5^{\text {th }}$ \\
\hline $\begin{array}{l}\text { Assets and } \\
\text { liabilities maturity } \\
\text { are analyzed. }\end{array}$ & 12 & 8 & 24 & 36 & 20 & 3.44 & $3^{\text {rd }}$ \\
\hline
\end{tabular}

\section{Marketing Risk Management}

Table -10 reveals that among three steps regarding marketing risk management, bank adopts the appropriate promotional activities to preserve its image occupies first rank, weighted average score being 3.48; followed by bank ensures appropriate but not excessive use of marketing entertainment and bank 
maintains proper procedures in awarding any external contract in bracket, weighted average scores being 3.24 each.

TABLE 10

OPINIONS REGARDING MARKETING RISK MANAGEMENT

\begin{tabular}{l|c|c|c|c|c|c|c}
\hline Steps & $\begin{array}{c}\text { Never } \\
(\%)\end{array}$ & $\begin{array}{c}\text { Seldom } \\
(\%)\end{array}$ & $\begin{array}{c}\text { Sometimes } \\
(\%)\end{array}$ & $\begin{array}{c}\text { Often } \\
(\%)\end{array}$ & $\begin{array}{c}\text { Always } \\
(\%)\end{array}$ & WAS & Ranks \\
\hline $\begin{array}{l}\text { Bank ensures appropriate } \\
\text { but not excessive use of } \\
\text { marketing entertainment. }\end{array}$ & 0 & 0 & 36 & 40 & 24 & 3.24 & $2.5^{\text {th }}$ \\
$\begin{array}{l}\text { Bank adopts the } \\
\text { appropriate promotional }\end{array}$ & 8 & 20 & 16 & 28 & 20 & 3.48 & $1^{\text {st }}$ \\
$\begin{array}{l}\text { activities to preserve its } \\
\text { image. }\end{array}$ \\
$\begin{array}{l}\text { Bank maintains proper } \\
\text { procedures in awarding } \\
\text { any external contract. }\end{array}$ & 4 & 12 & 24 & 36 & 24 & 3.24 & $2.5^{\text {th }}$ \\
\hline
\end{tabular}

Source: Field Survey, 2010

\section{Human Resource Risk Management}

Table -11 depicts that out of five measures regarding human resource risk management, bank complies with an effective human resource policy occupies first rank, weighted average score being 3.76; followed by bank maintains strict recruitment procedures; bank gives emphasis on pay and benefits for the employees; bank focuses on training \& development and bank emphasizes on disciplinary \& grievances, weighted average scores being 3.64; 3.44; 3.40 and 3.04 respectively.

TABLE11

OPINIONS REGARDING HUMAN RESOURCE RISK MANAGEMENT

\begin{tabular}{|c|c|c|c|c|c|c|c|}
\hline Steps & $\begin{array}{l}\text { Never } \\
(\%)\end{array}$ & $\begin{array}{l}\text { Seldom } \\
\text { (\%) }\end{array}$ & $\begin{array}{c}\text { Sometimes } \\
(\%)\end{array}$ & $\begin{array}{l}\text { Often } \\
(\%)\end{array}$ & $\begin{array}{c}\text { Always } \\
\text { (\%) }\end{array}$ & WAS & Ranks \\
\hline $\begin{array}{l}\text { Bank emphasizes on } \\
\text { disciplinary \& grievances. }\end{array}$ & 0 & 16 & 28 & 44 & 12 & 3.04 & $5^{\text {th }}$ \\
\hline $\begin{array}{l}\text { Bank complies with an } \\
\text { effective human resource } \\
\text { policy. }\end{array}$ & 8 & 4 & 24 & 32 & 32 & 3.76 & $1^{\mathrm{st}}$ \\
\hline $\begin{array}{l}\text { Bank focuses on training \& } \\
\text { development. }\end{array}$ & 12 & 4 & 32 & 36 & 16 & 3.40 & $4^{\text {th }}$ \\
\hline $\begin{array}{l}\text { Bank maintains strict } \\
\text { recruitment procedures. }\end{array}$ & 0 & 12 & 20 & 48 & 20 & 3.64 & $2^{\text {nd }}$ \\
\hline $\begin{array}{l}\text { Bank gives emphasis on } \\
\text { pay and benefit s for the } \\
\text { employees. }\end{array}$ & 8 & 16 & 28 & 20 & 28 & 3.44 & $3^{\text {rd }}$ \\
\hline
\end{tabular}

\section{Techniques for Managing Risk}

Table -12 reveals that among 10 techniques regarding risk management in the selected banks, Internal rating system occupies the first position, weighted 
average score being 4.04; followed by the risk adjusted rate of return on capital; gap analysis; value at risk; duration gap analysis and sensitivity analysis, weighted average scores being 3.96; 3.76; 3.68; 3.32 and 3.12 respectively.

TABLE 12

OPINIONS REGARDING USING OF TECHNIQUES FOR MANAGING RISK

\begin{tabular}{|c|c|c|c|c|c|c|c|}
\hline $\begin{array}{c}\text { Specific } \\
\text { Techniques }\end{array}$ & $\begin{array}{l}\text { Not used } \\
\text { at all (\%) }\end{array}$ & $\begin{array}{c}\text { Frequently } \\
\text { Used (\%) }\end{array}$ & $\begin{array}{c}\text { Neutral } \\
(\%)\end{array}$ & $\begin{array}{l}\text { Average } \\
\text { Used (\%) }\end{array}$ & $\begin{array}{c}\text { Highly } \\
\text { used (\%) }\end{array}$ & WAS & Rank \\
\hline $\begin{array}{l}\text { Risk Adjusted } \\
\text { Rate of Return } \\
\text { on Capital }\end{array}$ & 0 & 4 & 24 & 44 & 28 & 3.96 & $2^{\text {nd }}$ \\
\hline $\begin{array}{l}\text { Sensitivity } \\
\text { Analysis }\end{array}$ & 0 & 28 & 36 & 32 & 4 & 3.12 & $6^{\text {th }}$ \\
\hline $\begin{array}{l}\text { Internal Rating } \\
\text { System }\end{array}$ & 0 & 4 & 24 & 36 & 36 & 4.04 & $1^{\text {st }}$ \\
\hline Value at Risk & 0 & 16 & 24 & 36 & 24 & 3.68 & $4^{\text {th }}$ \\
\hline $\begin{array}{l}\text { Duration } \\
\text { Analysis }\end{array}$ & 0 & 28 & 32 & 20 & 20 & 3.32 & $5^{\text {th }}$ \\
\hline
\end{tabular}

Source: Field survey, 2010.

Note: Weighted average score is calculated using weights as follows: not used at all=1, frequently used=2, neutral $=3$, average used $=4$, and highly used $=5$.

\section{Maintenance of Guidelines of Bangladesh Bank for Managing Risk}

Table -13 depicts that out of five Bangladesh Bank Guidelines regarding risk management, asset liability management occupies the first position, weighted average score being 4.44; followed by investment risk management and foreign exchange risk management in bracket weighted average score being 4.20 each; prevention of money laundering and establishment of internal control and compliance, weighted average score being 1.40 and 1.24 respectively.

TABLE13

OPINIONS REGARDING USING OF BANGLADESH BANK GUIDELINES FOR MANAGING RISK

\begin{tabular}{|c|c|c|c|c|c|c|c|}
\hline Guidelines & $\begin{array}{c}\text { Not } \\
\text { followed } \\
\text { at all (\%) }\end{array}$ & $\begin{array}{l}\text { Frequently } \\
\text { followed } \\
\text { (\%) }\end{array}$ & $\begin{array}{l}\text { Neutral } \\
(\%)\end{array}$ & $\begin{array}{l}\text { Average } \\
\text { followed } \\
\text { (\%) }\end{array}$ & $\begin{array}{l}\text { Highly } \\
\text { followed } \\
\text { (\%) }\end{array}$ & WAS & Rank \\
\hline $\begin{array}{l}\text { Foreign Exchange Risk } \\
\text { Management }\end{array}$ & 0 & 8 & 32 & 24 & 36 & 4.20 & $2.5^{\text {th }}$ \\
\hline $\begin{array}{l}\text { Asset Liability } \\
\text { Management }\end{array}$ & 0 & 0 & 16 & 24 & 60 & 4.44 & $1^{\text {st }}$ \\
\hline $\begin{array}{l}\text { Investment Risk } \\
\text { Management }\end{array}$ & 0 & 8 & 16 & 24 & 52 & 4.20 & $2.5^{\text {th }}$ \\
\hline $\begin{array}{l}\text { Establishment of } \\
\text { Internal Control and } \\
\text { Compliance }\end{array}$ & 76 & 24 & 0 & 0 & 0 & 1.24 & 5th \\
\hline $\begin{array}{l}\text { Prevention of Money } \\
\text { Laundering }\end{array}$ & 60 & 40 & 0 & 0 & 0 & 1.4 & $4^{\text {th }}$ \\
\hline
\end{tabular}

Source: Field survey, 2010

Note: Weighted average score is calculated using weights as follows: not followed at all=1, frequently followed=2, neutral=3, average followed=4, and highly followed=5. 


\section{CONCLUSIONS}

On the basis of sample bankers' opinions the following (statistically significant) results can be concluded:

i) Of the various types of risks faced by the selected banks, credit risk, market risk and operational risk are the major risks to the bankers.

ii) Regarding risk management oversight, it is seen that the Board of Director performs the responsibility of the main risk oversight, the Executive Committee monitors risk and the Audit Committee oversees all the activities of banking operations.

iii) Regarding credit risk management, it is revealed that bank uses the updated credit policy approved by the Board of Director Credit risk management division and credit administration division perform their activities separately, law and recovery team monitors the performance of the loans. Internal control and compliance division directly reports to the Board/Audit Committee about the overall credit risk status.

iv) In terms of opinions as to operational risk management, it is found that operational risk is monitored and controlled within the bank through an operational risk management framework.

v) Regarding money laundering risk management, it is noticed that the Central Compliance Unit looks after the overall compliance with money laundering regulations.

vi) Regarding equity risk management, bank follows market-to-market valuations of the share investment portfolio in measuring and identifying risk.

vii) Regarding information technology risk management, it is reported that IT Audit Team audits the divisions and branches.

viii) Regarding managing the liquidity risk, it is found that bank maintains that customers' confidence is maintained in ensuring liquidity.

ix) Regarding marketing risk management, it is revealed that bank adopts the appropriate promotional activities to preserve its image.

$\mathrm{x}$ ) In human resource risk management it is found that bank complies with an effective human resource policy.

xi) Regarding use of risk management techniques, it is found that internal rating system and risk adjusted rate of return on capital are important.

xii) In the use of Bangladesh Bank guidelines for managing risks, it is revealed that asset liability management, investment risk management 
and foreign exchange risk management are much significant to the bankers.

In order to make the risk management effective in the selected commercial banks operating in Bangladesh, the major types of risks, e.g., credit risk, market risk, operational risk, interest rate risk, foreign exchange risk, equity risk, liquidity risk, money laundering risk, information technology risk, marketing risk and human resource risk need to be emphasized by the concerned bank authority. Moreover, the major techniques of risk management as mentioned in Table-12 and significant guidelines for managing risk given by Bangladesh Bank demand special care for the overall success of risk management.

\section{REFERENCES}

Allen, L. and Jagtiani, J. (1996). Risk and Market Segmentation in Financial Intermediaries’ Return. Wharton Financial Institutions Center, 1-32.

Bo, H., Qing-Pu, Z., and Yun-Quan, H. (2005). Research on Credit Risk Management of the State-Owned Commercial Bank. Proceedings of the Fourth International Conference on Machine Learning and Cybernetics, 1-6.

Crouhy, Michel, Dan Galai, and Robert Mark (2001), Risk Management, McGraw Hill, New York. pp. 543-48

Cumming, Christine and Beverly J. Hirtle (2001), “The Challenges of Risk Management in Diversified Financial Companies”, Economic Policy Review, Federal Reserve Bank of New York, 7, 1-17.

Diamond, D.W. (1999). Liquidity Risk, Liquidity Creation and Financial Fragility: A Theory of Banking. National Bureau of Economic Research, 1-55.

Gatev, E. (2006). Managing Bank Liquidity Risk: How Deposit-loan Synergies Vary with Market Conditions. National Bureau of Economic Research, 1-38.

Gleason, James T. (2000), Risk: The New Management Imperative in Finance, Bloomberg Press, Princeton, New Jersey. P.21

Hanweck, G., and Ryu, L. (2004). The Sensitivity of Bank Net Interest Margins to Credit, Interest Rate and Term Structure Shocks. [Online]. Available:

http://www.fdic.gov/bank/analytical/cfr/2004/sept/CFRSS_2004-02_Hanweck.pdf

Hasan, I., and Sarkar, S. (2002). Banks' Option to Lend, Interest Rate Sensitivity, and Credit Availability. Review of Derivatives Research, 5(3), 213-250.

Hendricks, D., \& Hirtle, B. (1997). Bank Capital Requirement for Market Risk: The Internal Models Approach. Economic Policy Review, 1-12.

Hyde, S. (2007). The Response of Industry Stock Returns to Market, Exchange Rate and Interest Rate Risks. Managerial Finance, 33(9), 693-709. 
Jorion, Phillippe and Sarkis J. Khoury (1996), Financial Risk Mangement Domestic and International Dimensions, Blackwell Publishers, Cambridge, Massachusetts. P.2

Jorion, Phillipe (2001), Value at Risk, The New Benchmark for Managing Financial Risk, McGraw Hill, New York.

King, J.L. (1998), Defining Operational Risk. Algo Research Quarterly, 1(2), 37-42.

Khan, T. \& Ahmad, H. (2001), Risk Management - An Analysis of Issues in Islamic Financial Industry, Occasional Paper No. 5, Islamic Research and Training Institute, Islamic Development Bank, Jeddah. P. 26

Medova, E.A. (2001). Operational Risk Capital Allocation and Integration of Risks. Centre for Financial Research, 1-23.

Pyle, H. David (1997); Bank Risk Management Theory, Working paper RPF-272, Haas School of Business, University of California, Berkeley.Page-2.

Santomero, Anthony M. (1997), "Commercial Bank Risk Management: An Analysis of the Process”, Journal of Financial Services Research, 12, 83-115.

Voon-Choong. Y, Hway-Boon, O, Kok-Thim, C, and Yueh-Sin, A, (2010). Factors Affecting Banks' Risk Exposure: Evidence from Malaysia. European Journal of Economics, Finance and Administrative Sciences, ISSN 1450-2887, Issue 19, pp. 121-122.

Wikipedia, Money Laundering, Available: http://en.wikipedia.org/ wiki/Money_ laundering. Retrieved on 12.30 PM, 9/20/11. 